\title{
Mycorrhizal symbiosis of alien and invasive tree species
}

\author{
Robin Wilgan \\ The Institute of Dendrology, Polish Academy Sciences, Laboratory of Symbiotic Associations, ul. Parkowa 5, 62-035 Kórnik, Poland \\ Tel. + 48 618170033, e-mail: rwilgan@man.poznan.pl
}

\begin{abstract}
The introduction of alien tree species has become a world wide phenomenon over the last centuries and the cultivation of these species is an economically important branch of forestry in many countries. However, the cultivation of alien plant species poses the threat of introducing potentially invasive species, both trees and its mutualistic symbionts, such as mycorrhizal fungi. Mycorrhizal fungi are obligatory symbionts and a key element in the proper development and functioning of trees. It is thought that mycorrhizal fungi may also profoundly influence the invasiveness of alien tree species worldwide, with the proper fungal species acting as a driver to make this invasion possible. Co-invasion of alien trees and its mutualistic symbionts are well-known in the case of pines and co-invading ectomycorrhizal fungi in the southern hemisphere.

Invasive tree species constitute a major ecological and economic problem through intense competition and modification of local habitats leading to a decline in biodiversity and potentially threatening many rare, native and endangered species, including fungi. Despite the fundamental role that fungi have in the functioning of forests, the impact alien tree species could have on mycorrhizal fungi in native forest ecosystems has not received much attention.

Understanding the relationships between mycorrhizal fungi and alien tree species can allow us to better predict and counter-act alien species invasions, which is necessary in order to maintain biodiversity and preserve native ecosystems. On top of that, climate change could threaten some European tree species and thus free ecological niches for other species, like alien, invasive or potentially invasive trees.
\end{abstract}

Keywords: ectomycorrhiza, arbuscularmycorrhiza, biological invasion, nature conservation, climate change

\section{Introduction}

Alien species are all those that occur outside their natural range and have been introduced as a result of human activity, either deliberately for cultivation or as inadvertently transported species (Richardson et al. 2000a). Alien plant species have been introduced in Europe since ancient times. Today, they play an important role in the European economy, making up a large share of cereal crops (e.g. wheat, barley), vegetables (e.g. potatoes, tomatoes), fruit trees (e.g. apples, peaches) (Eurostat 2018) and wood production (e.g. black locust Robinia L.) (Krumm and Vítková 2016).

Over the last few centuries, the cultivation of trees of foreign origin has become a common phenomenon, with the risk of biological invasion both of the trees and their associated symbionts such as mycorrhizal fungi (Nunez and Dickie 2014). Invasive tree species, i.e. those alien species able to spontaneously and rapidly spread beyond their natural range (Richardson et al. 2000a), modifying local ecosystems and displacing native species, pose a serious threat to the maintenance of native ecosystem diversity (Butchart et al. 2010). In the process of the invasion and spread of alien tree species, an important role is played by the mycorrhizal symbiosis they establish (Richardson et al. 2000b; Pringle et al. 2009; Dickie et al. 2010).

\section{History of the introduction of alien tree species in Europe}

With the exploration and colonisation of new lands begun with the discovery of America in 1492, alien tree species

Received: 19.12.2019 r., accepted after revision: 6.02.2020 r. 
were introduced to Europe on a heretofore unprecedented scale. Since the 16th century, numerous botanical gardens have been established in Europe, dedicated to the collection and breeding of plants from all over the world, as well as to research on their acclimatisation and cultivation potential. Particular attention was paid to plants from North America, as the climatic conditions in the USAand Canada are similar to those in Europe. When industrialisation progressed andthe wood resources of European forests began to shrinkat the end of the 19thcentury, alien tree species began to be tested for use in forest management. Pioneering research in this field was conducted by German and Austrian foresters, Schwappach, Cieslar and Wiedemann, who at the turn of the 19th and $20^{\text {th }}$ centuries, established numerous experimental areas with alien tree species in the forests of central Europe. Some of the more than 50 alien tree species they introduced into the forests, such as the red oak Quercus rubra L., white pine pinus strobus L. and Douglas fir Pseudotsuga menziesii (Mirb.) Franco, gave satisfactory results for woodproduction. This led to the mass planting of these trees in European forests (Białobok and Chylarecki 1965), where they began to spread spontaneously over time (Krumm and Vítková 2016).

Of the many introduced alien species, few tend to expand beyond their natural range and become invasive (Richardson et al. 2000a). The presence of invasive species is an important issue for modern nature conservation and management. Through habitat modification and competition for food resources, alien tree species affect local ecosystems and can endanger native species, including rare and threatened ones, and lead to a decline in biodiversity (Butchart et al. 2010; Dueñas et al. 2018). Numerous measures are being taken at the national and international levels to limit the expansion of invasive species; yet in Europe alone, invasive plant species generate losses estimated at EUR 4 billion per year (Kettunen et al. 2008).

\section{The symbiosis of alien and invasive tree species and its significance}

Recent studies have pointed out that mycorrhizal symbiosis, i.e. the relationship between plant roots and fungi (Smith and Read 2008), may play an important role in the process of the plant invasions (Richardson et al. 2000b; Pringle et al. 2009). The most common type of tree symbiosis in temperate and boreal zone forests is ectomycorrhiza (EM), which is formed together by different types of trees (e.g. oaks, beeches, hornbeams, pines and spruces) and many species of fungi from the Basidiomycota division (e.g. porcini, chanterelles, milk-cap mushrooms) and sac fungi (e.g. truffles). Some trees (e.g. maples, ash, chestnut trees) form arbuscular mycorrhiza (AM) with fungi from the Glomeromycota division. Mycorrhizal symbiosis is mutualistic, i.e. mutually beneficial for both partners of the symbiotic relationship: mycorrhizal fungi receive carbohydrates from trees and provide trees with increased access to water and mineral salts and protect against pathogens and adverse environmental conditions thatdetermine their proper development (Smith and Read 2008). Therefore, mycorrhizal symbiosis should be considered a factor that can affect the spread of alien tree species outside their natural range. The dispersion of alien tree species depends on their ability to reproduce in new areas, competition from other organisms, or the availability of ecological niches. In the 1990s, the 'enemy release hypothesis' was formulated, which assumes that alien species have no natural enemies, such as pathogens or specialised herbivores, in the new area, which makes it easier for them to compete with native species and, as a result, enables them to spread (Keane and Crawley 2002). Callaway et al. (2011) indicated that the invasiveness of black locust Robinia pseudoacacia L. in Europe may be increased by the absence of parasites from its natural range, such as the fungus Fomes rimosus (Berk.) Cooke or the beetle Megacyllene robiniae Forster. Similar observations, indicating that the absence of natural enemies may increase the invasiveness of alien species, were made for the box elder Acer negundo L. and the American black cherry Prunus serotina Ehrh. (Reinhart et al. 2003; Reinhart and Callaway 2004). Further research has allowed hypotheses to be formulatedon the role of mutualistic symbiosis in the invasion process of alien species. The enhanced mutualism hypothesis assumes that the establishment by species growing outside their natural range of new, more efficient symbiotic relationships facilitates the spread of alien species (Reinhart and Callaway 2006). In turn, the degraded mutualism hypothesis states that invasive species benefit less from symbiosis and are therefore less dependent on it than native species (Vogelsang and Bever 2009). So far, these hypotheses have not been unequivocally confirmed in studies of the mycorrhizal fungi associated with alien tree species (Bunn et al. 2015).

Alien tree species, growing outside their natural range, can establish a mycorrhizal symbiosis with cosmopolitan fungi, both in the natural range of the alien tree species as well as in the new area, and also with native fungi that do not occur in its natural range. However, the spread of alien tree species may depend on the presence of specific fungi that only occur in the tree's natural range (Pringle et al. 2009; Dickie et al. 2010). When alien tree species establish symbiosis with alien fungal species that have been transported together with the trees, we can then call it a co-invasion of trees and fungi of alien origin (Nunez and Dickie 2014). 
Most invasive tree species in Europe develop symbiosis with arbuscular fungi (Table 1). Many of the approximately 250-350 identified arbuscular fungi are global species that are not specific to a plant partner (Davison et al. 2015). This means that few places in the world can be considered to be 'free' from compatible arbuscular fungi. It has been shown that plants of foreign origin, including the most invasive tree species in Europe, such as the box elder, the American black cherry or the black locust, are commonly associated in symbiosis with widely distributed arbuscular fungi (Moora et al. 2011; Majewska et al. 2015). Thus, it can be concluded that alien tree species, forming AM, do not need arbuscular fungi to be transported from their natural range to become invasive species.

In contrast to AM, ectomycorrhizal symbiosis is co-created by many fungal species belonging to 160 genera from 66 phylogenetic lines (Tedersoo et al. 2010). It is assumed that there may be as many as 25,000 species of ectomycorrhizal fungi (Rinaldi et al. 2008). Trees may establish mycorrhizal symbiosis both with non-specialised ectomycorrhizal symbionts, such as Cenococcum geophilum Fr. or Paxillus involutus (Batsch) Fr.,as well as with specialisedsymbionts. Examples of specialised symbionts are various fungal species in the genusSuillus P. Micheli spp., which are associated with pines and occur in the range of pines in the temperate and boreal zones of the Northern Hemisphere (Tedersoo et al. 2010).

Pines are among the most invasive tree species in the world. The Pinaceaepine family includes 32 invasive species: 23 pine species and single species of spruce, fir, larch and Douglas fir (Rejmánek and Richardson 2013). Pines were widely introduced beyond their natural range and are still cultivated worldwide today. Due to their high productivity, pine cultivation was often established in countries of the Southern Hemisphere, including Australia and southern Africa. Initially, these crops were unsuccessful, which changed only after the introduction of ectomycorrhizal fungi from the natural range of pines in Europe and North America (Pringle et al. 2009; Nunez et al. 2017). Currently, it is believed that out of about 200 known alien species of ectomycorrhizal fungi, more than half (57\%) were transported together with pines and other tree species from the pine family, and of this number,one third (more than 40 species) were suilloidfungi: slippery jacks Suillus and false truffles Rhizopogon Fr. (Vellinga et al. 2009).

The presence of suilloid fungi plays a key role in pine invasions (Policelli et al. 2018). Slippery jacks andfalse truffles, which are associated with pines in the first stages of tree development (Rudawska et al. 2018a), form an EM of the so-called 'long-distance exploration type' (reproductive structure, extensive external mycelia, long mycelial cords). These exploration types of fungi penetrate larger areas of soil, obtaining water and mineral salts more efficiently. As a result, suilloid fungi allow trees to spread beyond the point of their introduction (Hayward et al. 2015), especially in ecosystems where trees have not yet been found, such as the pampas of Argentina (Pauchard et al. 2015). It is, therefore, possible to speak of a co-invasion of pines and suilloid fungi.

Despite the presence of ectomycorrhizal fungi associated with pines in Europe, alien pine species such as white pine P. strobus and Douglas fir Pinus contorta Dougl. ex Loud. originating in North America are less invasive than in the Southern Hemisphere. Similarly, European pine species, such as Scots pine Pinus sylvestris L. and mountain pine Pinus mugo Turra, are relatively less expansive in North America (Nunez et al. 2017). This may be due to the presence in Europe and North America - the natural range of pines - of specific pine pathogens and parasites, such as the fungus Sphaeropsis sapinea (Fr.) Dyko \& B. Sutton, which can limit the spread of alien pine species (Mortenson and Mack 2006). This is in line with the assumptions of the enemy release hypothesis because beyond the natural range of pines, e.g. in Australia and New Zealand, there are no pine-related parasites and pathogens, which makes the spread of alien pine species more effective.

The co-invasion of alien species - trees and ectomycorrhizal fungi - is particularly relevant to the southern region of Europe, where exotic tree species are grown, such as eucalyptus. The co-invasion of eucalyptus and its fungi was first widely described from the Iberian Peninsula, where ectomycorrhizal fungi, alien in Europe, were transported together with the eucalyptus, including Descolea alba (Klotzsch) Kuhar, Nouhra \& M.E. Sm, Reddellomyces potkii (Malençon) Trappe, Castellano \& Malajczuk, (closely related to truffles) and Setchelliogaster rheophyllus (Bertault \& Malençon) G. Moreno \& Kreisel (Diez et al. 2005) originating in Australia. Subsequent examples of eucalyptus and fungi co-invasions have also been described in Africa, Madagascar and Brazil, among others. It is now believed that about one-fourth of alien ectomycorrhizal fungi species may have been introduced together with eucalypti (Vellinga et al. 2009), and the eucalypti themselves are considered to be invasive species in many countries, including Spain, Brazil, the USA and India.

The issue of ectomycorrhizal fungi co-invasions with their plant partners does not encompass all alien tree species. In Europe, the invasive red oak Q. rubra establishes symbiosis with European fungi species (Trocha et al. 2012). It is worth noting that the alien red oak, growing in the immediate vicinity of the European pedunculate oak Quercus robur L., formed symbiosis with fewer fungi species than 
Table 1. Symbiotic relations of invasive alien tree species with special emphasis on Europe

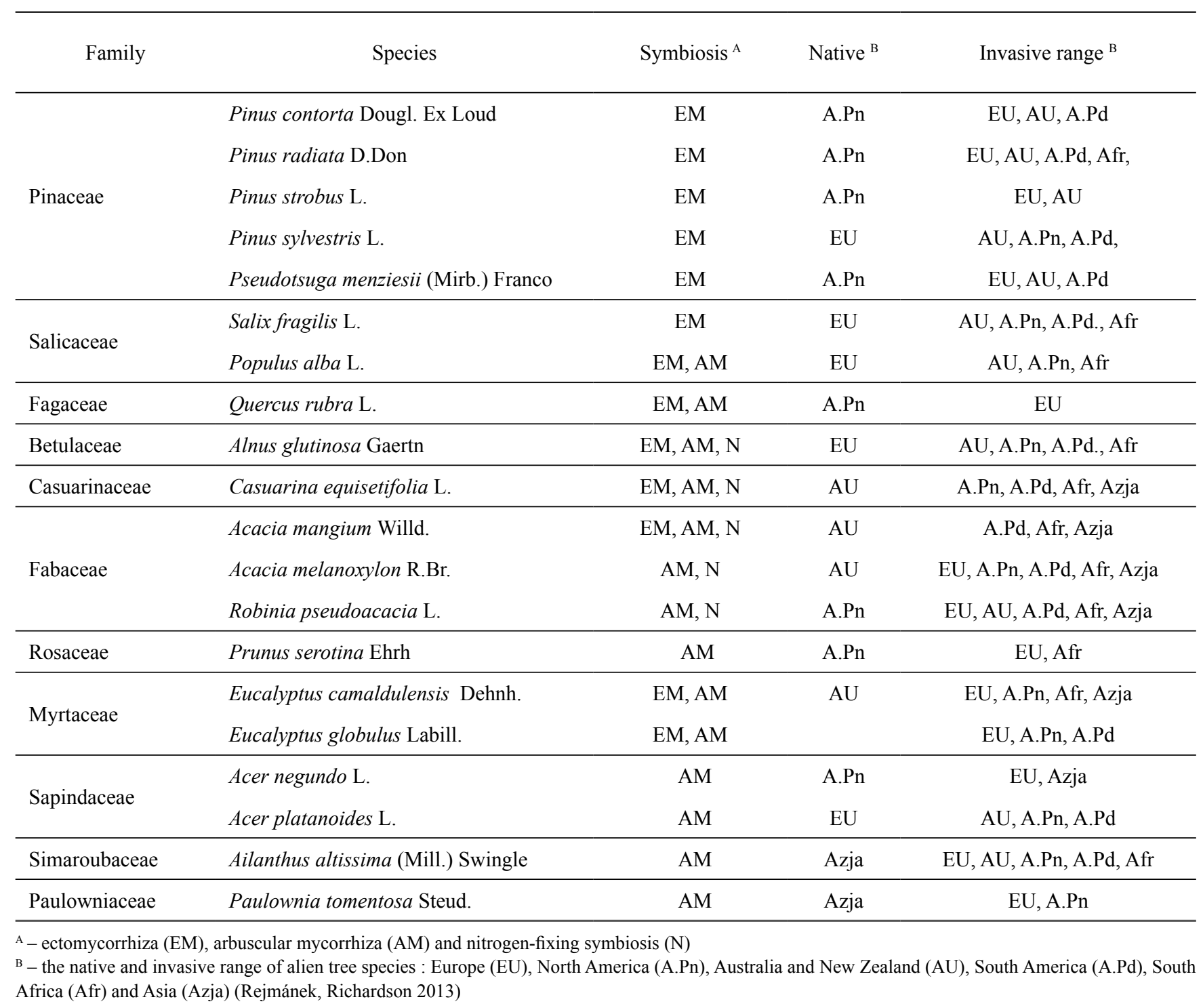

the native species and did not establish symbiosis, e.g. with oak milkcap Lactarius quietus (Fr.) Fr., which co-creates one-third of the EM of pedunculate oak (Trocha et al. 2012). This suggests some differences in the establishment of mycorrhizal symbiosis between native and alien oak species. This may be due to the fact that they belong to two genetically different groups of oaks: the North American Lobatae section (red oak) and the Quercus section (pedunculate oak), which differ, among others, in the content of lignins and tannins in the leaves (Moreira et al. 2018). This may affect the chemical composition of the leaf litter (Skorupski et al. 2012), and thus also the ectomycorrhizal fungi (Lilleskov et al. 2011).
An interesting example of alien tree species in Europe is the hickory Carya Nutt. spp., which in their natural range in North America occur together with the red oak, creating oak-hickory forests that resemble hornbeam forests. The hickories growing in European forests do not exhibit the characteristics of invasive species (Tokarska-Guzik et al. 2012; Paź et al. 2018), and the ectomycorrhizal fungi communities associating with themare formed exclusively by European fungi species, the majority (90\%) of which are oak symbionts. These communities are characterised by high diversity (about 100 species) (Rudawska et al. 2018b; Wilgan et al. 2019), comparable to and even higher than the diversity of ectomycorrhizal fungi in native oak-hornbeam forests 
(Wilgan et al. 2019). Perhaps this reflects the assumptions of the degraded mutualismhypothesis, wherein alien species that have become invasive (such as red oak) would become symbiotic with fewer fungal species and be less dependent on symbiosis than non-invasive alien species such as hickories. However, further research is needed to verify this hypothesis.

Oaks and closely related tree genera such as beeches, hornbeams, alders and birches, some of the main deciduous species in the temperate forests of Europe and North America, become invasive relatively rarely. Only individual alien species from the Fagaceae family (five species, including the red oak, Asian sawtooth oak Quercus acutissima Carruth., invasive in North America, or the pedunculate oak, invasive in southern Africa) and the Betulaceae family (three species: filbert Corylus maxima Mill., black alder Alnus glutinosa Gaertn. and silver birch Betula pendula Roth, invasive in, among others, North America) have been recognised as invasive species, despite the wide geographical range and the high diversity of these families (more than 1100 species in total). This is not much compared to other tree families, such as pine (Pinaceae), which includes 32 invasive species, Myrtaceae with 31 invasive tree species, including eucalyptus, and Fagaceae, which includes 89 invasive tree species, including 30 acacia species (Rejmánek and Richardson 2013). Trees such as oaks, beeches and hornbeams are characterised by relatively slow growth and heavy seeds. As a result, they are less frequently cultivated outside their natural range and at the same time spread more slowly than fastgrowing, pioneering tree species such as pines, eucalyptus and acacias (Dodet and Collet 2012).

One of the factors facilitating the spread of alien tree species may be the ability of some of them to establish dual mycorrhizal symbiosis, i.e. they are able to associate simultaneouslywith EM and AM. This type of symbiosis occurs in trees such as eucalyptus, willows and poplars, which include numerous invasive species, e.g. silver poplar Populus alba L., invasive in Australia and North America. Dual mycorrhizal symbiosis also occurs, among others, in the invasive black alder A. glutinos in North America or in the red oak (Dickie et al. 2001). Tree species which are dominated by EM, but at the same time are capable of establishing arbuscular mycorrhizal symbiosis, especially in the first stages of plant development and in difficult habitat conditions, may be more competitive with native species (Brundrett and Tedersoo 2018). This makes some species, such as eucalyptus and red oak, relatively more likely to become invasive.

Another example of dual symbiosis that can support the spread of invasive tree species is AM supported by symbiosis with dark septate endophytes (DSE), which has a positive effect on tree growth (Reininger and Sieber 2013). This type of symbiosis was found inailanthus Ailanthus altissima (Mill.) Swingle, an invasive species in Europe and North America, among others. Growing beyond its natural range, Ailanthus can establish symbiosis with local DSE fungi (Knapp et al. 2012), which is likely to promote its spread.

The spread of invasive tree species can also be supported by tripartite symbiosis between plants, mycorrhizal fungi and nitrogen-fixing bacteria. This type of symbiosis is characteristic of the legume family (Fabaceae), which includes $20 \%$ of known invasive tree species, including, among others, black locust (Rejmánek and Richardson 2013);this also occursin alders Alnus Mill. and Casuarina L. Nitrogen -fixing bacteria supply trees with assimilable nitrogen compounds, which makes it easier for thealien tree species to acclimatise to poor habitats and increases their potentialto spread.

\section{The effects of alien tree and fungi species on native mycobiota}

The impact of alien tree species on native mycorrhizal species is not well known. Alien tree species can modify soil chemistry and habitat conditions (Skorupski et al. 2012), transforming the habitat into a more suitable one for species with specific requirements (Chabrerie et al. 2010; Vítková et al. 2017). As a consequence, the massive occurrence of alien tree species may lead to the degradation of native ecosystems (Dodet and Collet 2012; Tokarska-Guzik et al. 2012), as well as the displacement of native fungal species, thus threatening native mycobiota. For example, black locust, by enriching the habitat with nitrogen, may create favourable conditions for the development of nitrophilous fungi. At the same time, enriching the soil with nitrogen adversely affects the occurrence of ectomycorrhizal fungi sensitive to high nitrogen content, such as slippery jacks or porcini (Lilleskov et al. 2011).

The co-invasion of alien tree and fungi species carries a number of threats to native species and ecosystems. For example, fly agaric Amanita muscaria (L.) Lam., an invasive species in New Zealand, becomes symbiotic with the southern beeches Nothofagus Blume spp. growing there, and the massive occurrence of this fungus in local forests poses a threat to native and endemic New Zealand ectomycorrhizal fungi (Orlovich and Cairney 2004). Similarly, the gumtree deceiver Laccaria fraterna (Sacc.) Pegler, transported to Europe with eucalyptus, establishes symbiosis with European labdanum Cistus ladanifer L., but its impact on the native fungi it associates with is not yet known. The question of whether native ectomycorrhizal fungi are being displaced by alien fungal species remains unanswered in many cases. However, it has been documented that the Asian black truffle Tuber indicum 
Cooke \& Massee transported to European truffle gardens displaces the valuable truffle species cultivated there (Murat et al. 2008). It can, therefore, be expected that native fungi species can be similarly displaced by alien ectomycorrhizal fungal species in other cases. Alien fungal species can also pose a threat to humans. The deadly poisonous death cap $A m a-$ nita phalloides (Vaill. ex Fr.) Link was transported to North America and Africa, among others, where it causes numerous fatal poisonings of the local residents (Wolfe et al. 2010).

In light of observed climate change, the spread of alien tree species outside their natural range may change. Climate change is leading to altered environmental conditions, which may affect key factors in the expansion of alien species, such as competition and the availability of ecological niches. Modelling changes in the ranges of major European tree species showa trend towards a shift in the climatic optimum. The ranges of species such as pedunculate oak $Q$. robur, Scots pine $P$. sylvestris or silver birch $B$. pendula are shifting towards the north and withdrawing from central Europe (Dyderski et al. 2017). It is believed that this may result in the 'release' of ecological niches, which may benefit alien species. With climate change, some alien species, such as the black locust and the box elder, may significantly increase their range and share in native ecosystems (Camenen et al. 2006; Dyderski et al. 2017), which may adversely affect the mycorrhizal relationships of native tree species.

\section{Conclusion}

Mycorrhizal symbiosis supports the acclimatisation of alien tree species and plays a key role in the spread of alien and invasive species. Research to date has shown that the presence of appropriate mycorrhizal symbionts can enable and accelerate the spread of alien tree species. Another factor facilitating this spread of alien tree species outside their natural range may be the ability of some of them to simultaneously establish several forms of symbiotic relationships.

By establishing different forms of symbiosis and modifying local habitats in different ways, alien tree species interact with native ecosystems and their elements, including mycorrhizal fungi, which are essential for the proper functioning of forests. However, the impact of alien and invasive tree species on Europe's native mycobiota remains a little studied topic and the invasiveness of alien tree species may increase with climate change.

Further research into the interaction between alien tree species, representing different degrees of invasiveness and different strategies for establishing symbiosis, and mycobiotics in native forests is required to better understand the mechanisms guiding the dynamics of the spread of alien tree species. Understanding the relationship between alien tree species and mycobiotic fungi can help us better anticipate and prevent the spread of alien species in native ecosystems, which is essential for the protection and conservation of biodiversity.

\section{Conflict of interest}

The author declares that there are no potential conflicts of interest.

\section{Acknowledgements and source of funding}

This review article was written within the framework of the statutory activities of the Institute of Dendrology of the Polish Academy of Sciences in Kórnik.

\section{References}

Białobok S., Chylarecki H. 1965. Badania nad uprawą drzew obcego pochodzenia w Polsce w warunkach środowiska leśnego. Arboretum Kórnickie 10: 211-277.

Brundrett M.C., Tedersoo L. 2018. Evolutionary history of mycorrhizal symbioses and global host plant diversity. New Phytologist 220:1108-1115. DOI 10.1111/nph.14976.

Bunn R.A., Ramsey P.W., Lekberg Y. 2015. Do native and invasive plants differ in their interactions with arbuscular mycorrhizal fungi? A meta-analysis. Journal of Ecology 103: 1547-1556. DOI 10.1111/1365-2745.12456.

Butchart S.H., Walpole M., Collen B., van Strien A., Scharlemann J.P. i in. 2010. Global biodiversity: indicators of recent declines. Science 328: 1164-1168. DOI 10.1126/science.1187512.

Callaway R.M., Bedmar E.J., Reinhart K.O., Silvan C.G., Klironomos J. 2011. Effects of soil biota from different ranges on Robinia invasion: acquiring mutualists and escaping pathogens. Ecology 92: 1027-1035. DOI 10.1890/10-0089.1.

Camenen E., Porté A.J., Benito Garzón M. 2016. American trees shift their niches when invading Western Europe: Evaluating invasion risks in a changing climate. Ecology and Evolution 6:7263-7275. DOI 10.1002/ece3.2376.

Chabrerie O., Loinard J., Perrin S., Saguez R., Decocq G. 2010. Impact of Prunus serotina invasion on understory functional diversity in a European temperate forest. Biological Invasions 12(6): 1891-1907. DOI 10.1007/s10530-009-9599-9.

Davison, J., M. Moora, M. Öpik, A. Adholeya, Ainsaar L., Bâ A., Burla S., Diedhiou A.G. i in. 2015. Global assessment of arbuscular mycorrhizal fungus diversity reveals very low endemism. Science 349: 970-973. DOI 10.1126/science.aab1161.

Dodet M., Collet C. 2012. When should exotic forest plantation tree species be considered as an invasive threat and how should we treat them? Biological Invasions 14: 1765-1778. DOI 10.1007/s10530-012-0202-4.

Dickie I.A., Bolstridge N., Cooper J.A.,Peltzer D.A., Duane A. 2010. Co-invasion by Pinus and its mycorrhizal fungi. New Phytologist 187: 475-484. DOI 10.1111/j.1469-8137.2010.03277.x. 
Dickie I.A., Koide R.T., Fayish A.C. 2001. Vesicular-arbuscular mycorrhizal infection of Quercus rubra seedlings. New Phytologist 151: 257-264. DOI 10.1046/j.1469-8137.2001.00148.x.

Díez J. 2005. Invasion biology of Australian ectomycorrhizal fungi introduced with eucalypt plantations into the Iberian Peninsula. Biological Invasions 7(1):3-15. DOI 10.1007/s10530-004-9624-y.

Dueñas M.A., Ruffhead H.J., Wakefield N.H., Roberts P.D., Hemming D.J., Diaz-Soltero H. 2018. The role played by invasive species in interactions with endangered and threatened species in the United States: a systematic review. Biodiversity and Conservation 27: 3171. DOI 10.1007/s10531-018-1595-x.

Dyderski M.K., Paź S., Frelich L.E., Jagodzi A.M. 2018. How much does climate change threaten European forest tree species distributions? Global Change Biology 24: 11501163. DOI $10.1111 / \mathrm{gcb} .13925$.

Eurostat. 2018. Agriculture, Fishery and Forestry Statistics. ISBN 978-92-79-94757-5. DOI 10.2785/340432.

Hayward J., Horton T.R., Pauchard A., Nuñez M.A. 2015. A single ectomycorrhizal fungal species can enable a Pinus invasion. Ecology 96: 1438-1444. DOI 10.1890/14-1100.1.

Keane R.M., Crawley M.J. 2002. Exotic plant invasions and the enemy release hypothesis. Trends in Ecology \& Evolution 17(4): 164-170. DOI 10.1016/S0169-5347(02)02499-0.

KettunenM.,GenovesiP., GollaschS.,PagadS.,StarfngerU.,tenBrink P., Shine C. 2008. Technical support to EU strategy on invasive species (IAS). Assessment of the impacts of IAS in Europe and the EU. Institute for European Environmental Policy, Brussels http://ec.europa.eu/environment/nature/invasivealien/docs/ Kettunen2009_IAS_Task\%201.pdf [19.12.2020].

Knapp D.G., Pintye A., Kovács G.M. 2012. The dark side is not fastidious -dark septate endophytic fungi of native and invasive plants of semiarid sandy areas. PLoS One 7(2): e32570. DOI 10.1371/journal.pone.0032570.

Krumm F., Vítková L. 2016. Introduced tree species in European forests: opportunities and challenges. European Forest Institute, 4-425. ISBN 978-952-5980-32-5.

Lilleskov E.A., Hobbie E.A., Horton T.R. 2011. Conservation of ectomycorrhizal fungi: exploring the linkages between functional and taxonomic responses to anthropogenic $\mathrm{N}$ deposition. Fungal Ecology 4(2): 174-183. DOI 10.1016/j. funeco.2010.09.008.

Majewska M.L., Błaszkowski J., Nobis M., Rola K., Nobis A., Łakomiec D., Czachura P., Zubek S. 2015. Rootinhabiting fungi in alien plant species in relation to invasion status and soil chemical properties. Symbiosis 65: 101-115.

Moora M., Berger S., Davison J., Öpik M., Bommarco R., Bruelheide H., Kühn I., Kunin W.E., Metsis M.1. i in. 2011. Alien plants associate with widespread generalist arbuscular mycorrhizal fungal taxa: evidence from a continental-scale study using massively parallel 454 sequencing. Journal of Biogeography 38: 1305-1317. DOI 10.1111/j.1365-2699.2011.02478.x.

Moreira X., Abdala-Roberts L., Galmán A., Francisco M., Fuente M.D., Butrón A., Rasmann S. 2018. Assessing the influence of biogeographical region and phylogenetic history on chemical defences and herbivory in Quercus species. Phytochemistry 153: 64-73. DOI 10.1016/j.phytochem.2018.06.002.
Mortenson S.G., Mack R.N. 2006. The fate of alien conifers in long-term plantings in the USA. Diversity and Distributions 12(4): 456-466. DOI 10.1111/j.1366-9516.2006.00274.x.

Murat C., Zampieri E., Vizzini A., Bonfante P. 2008. Is the Perigord black truffle threatened by an invasive species? We dreaded it and it has happened! New Phytologist 178: 699-702. DOI 10.1111/j.1469-8137.2008.02449.x.

Nuñez M.A., Chiuffo M.C., Torres A., Paul T., Dimarco R.D., Raal P., Policelli N., Moyano J., García R.A., van Wilgen B.W., Pauchard A., Richardson D.M. 2017. Ecology and management of invasive Pinaceae around the world: Progress and challenges. Biological Invasions 19: 3099-3120. DOI 10.1007/ s10530-017-1483-4.

Nuñez M.A., Dickie I.A. 2014. Invasive belowground mutualists of woody plants. Biological Invasions 16:645-661. DOI 10.1007\%2Fs10530-013-0612-y.

Orlovich D.A., Cairney J.W.G. 2004. Ectomycorrhizal fungi in New Zealand: current perspectives and future directions. New Zealand Journal of Botany 42: 721-738. DOI 10.1080/00288 25X.2004.9512926.

Pauchard A., Escudero A., García R.A., de la Cruz M., Langdon B., Cavieres L.A., Esquivel J. 2016. Pine invasions in treeless environments: dispersal overruns microsite heterogeneity. Ecology and Evolution 6: 447-459. DOI: 10.1002/ece3.1877.

Paź S., Czapiewska N., Dyderski M.K., Jagodziński A.M. 2018. Ocena introdukcji Carya ovata (Mill.) K. Koch na siedlisku grądu w Nadleśnictwie Czerniejewo. Sylwan 162(1): 41-48. DOI 10.26202/sylwan.2017094.

Policelli N., Bruns T.D., Vilgalys R., Nuñez M.A. 2019. Suilloid fungi as global drivers of pine invasions. New Phytologist 222(2): 714-725. DOI 10.1111/nph.15660.

Pringle A., Bever J.D., Gardes M., Parrent J.L., Rillig M.C. Klironomos J.N., 2009. Mycorrhizal Symbioses and Plant Invasions. Annual Review of Ecology, Evolution, and Systematics 40: 699-715. DOI 10.1146/annurev.ecolsys.39.110707.173454.

Reinhart K.O., Callaway R.M. 2004. Soil biota facilitate exotic Acer invasions in Europe and North America. Ecological Applications 14: 1737-1745. DOI 10.1890/03-5204.

Reinhart K.O., Callaway R.M. 2006. Soil biota and invasive plants. New Phytologist 170(3): 445-457. DOI 10.1111/j.1469-8137.2006.01715.x.

Reinhart K.O., Packer A., Van der Putten W.H., Clay K. 2003. Plant $\square$ soil biota interactions and spatial distribution of black cherry in its native and invasive ranges. Ecology Letters 6: 1046-1050. DOI 10.1046/j.1461-0248.2003.00539.x.

Reininger V., Sieber T.N. 2013. Mitigation of antagonistic effects on plant growth due to root co-colonization by dark septate endophytes and ectomycorrhiza. Environmental Microbiology Reports 5(6): 892-898. DOI 10.1111/1758-2229.12091.

Rejmánek M., Richardson D. M. 2013. Trees and shrubs as invasive alien species - 2013 update of the global database. Diversity and Distributions 19(8): 1093-1094. DOI 10.1111/ddi.12075.

Richardson D.M., Pyšek P., Rejmánek M., Barbour M.G., Panetta F.D., West C.J.2000a. Naturalization and invasion of alien plants: concepts and definitions. Diversity and Distributions 3(6): 14-93. DOI 10.1046/j.1472-4642.2000.00083.x. 
Richardson D.M., Allisopp N., D'Antonio C.M., Milton S.J., Rejmanek M. 2000b. Plant invasions-theroleofmutualisms. Biological Reviews 75: 65-93. DOI 10.1017/s0006323199005435.

Rinaldi A.C., Comadini O., Kuyper T.W. 2008. Ectomycorrhizal fungal diversity: separating the wheat from the chaff. Fungal Divers 33: 1-45.

Rudawska M., Wilgan R., Janowski D., Iwański M., Leski T. 2018a. Shifts in taxonomical and functional structure of ectomycorrhizal fungal community of Scots pine (Pinus sylvestris L.) underpinned by partner tree ageing. Pedobiologia 71: 2030. DOI 10.1016/j.pedobi.2018.08.003.

Rudawska M., Leski T., Wilgan R., Karliński L., Kujawska M., Janowski D. 2018b. Mycorrhizal associations of the exotic hickory trees, Carya laciniosa and Carya cordiformis, grown in Kórnik Arboretum in Poland. Mycorrhiza 28: 549560. DOI 10.1007/s00572-018-0846-8.

Skorupski M., Jagodzinski A.M., Zytkowiak R., Karolewski P. 2012. Differences in chemical composition of needle and leaf litter from exotic and native tree species stands. Dendrobiology 68: 101-112.

Smith S.E., Read D.J. 2008. Mycorrhizal Symbiosis $3^{\text {rd }}$ Edition, Academic Press, London.

Tedersoo L., May T.W., Smith M.E. 2010. Ectomycorrhizal lifestyle in fungi: Global diversity, distribution and evolution of phylogenetic lineages. Mycorrhiza 20(4): 217-263. DOI 10.1007/s00572-009-0274-x.

Tokarska-Guzik B., Dajdok Z., Zając M., Zając A., Urbisz A., Danielewicz W., Hołdyński C. 2012. Rośliny obcego pochodzenia w Polsce ze szczególnym uwzględnieniem gatunków inwazyjnych. Wydawnictwo Generalnej Dyrekcji Ochrony Środowiska, Warszawa,4-195. ISBN 978-83-62940-34-9.

Trocha L.K., Kałucka I., Stasińska M., Nowak W., Dabert M., Leski T., Rudawska M., Oleksyn J. 2012. Ectomycorrhizal fungal communities of native and non-native Pinus and Quercus species in a common garden of 35-year-old trees. Mycorrhiza 22: 121-134. DOI 10.1007/s00572-011-0387-x.

Vellinga E.C., Wolfe B.E., Pringle A. 2009. Global patterns of ectomycorrhizal introductions. New Phytologist 181: 960-973. DOI 10.1111/j.1469-8137.2008.02728.x.

Vítková J., Müllerová J., Sádlo J., Pergl J., Pyšek P. 2017. Black locust (Robinia pseudoacacia) beloved and despised: a story of an invasive tree in Central Europe. Forest Ecology and Management 384: 287-302. DOI 10.1016/j. foreco.2016.10.057.

Vogelsang K.M., Bever J.D. 2009. Mycorrhizal densities decline in association with nonnative plants and contribute to plant invasion. Ecology 90(2): 399-407. DOI 10.1890/07-2144.1.

Wilgan R., Leski T., Kujawska M., Karliński L., Janowski D., Rudawska M. 2020. Ectomycorrhizal fungi of exotic Caryaovata (Mill.) K. Koch in the context of surrounding native forests on Central European sites. Fungal Ecology (in print).

Wolfe B.E., Richard F., Cross H.B., PringleA. 2010. Distribution and abundance of the introduced ectomycorrhizal fungus $\mathrm{Am}$ anita phalloides in North America. New Phytologist 185: 803816. DOI 10.1111/j.1469-8137.2009.03097.x. 